\section{Sir Eric Rideal}

Sir ERIC Rideal, MBE, FRS, the distinguished physical chemist, died on September 25, 1974. He was 84.

From Trinity Hall, Cambridge, Rideal went to Bonn and obtained his PhD there in 1913. After service in the Munitions Inventions Service, he returned to Cambridge in 1920 as Humphrey Owen Jones Lecturer in Physical Chemistry and ten years later became the first Professor of Colloidal Physics. In 1946 he left to be Director of the Davy-Faraday Research Institute and Fullerian Professor at the Royal Institution. He was appointed to the chair of physical chemistry at King's College, London, in 1950 . He retired from this post in 1955 and was elected a Fellow in 1963. After his retirement he continued working at Imperial College, London.

\section{H. A. Ferreira}

Herculano de Amorim Ferreira, the Portuguese climatologist, died on May 18,1974 . He was 78.

Ferreira became a professor at the Faculty of Sciences, Lisbon University in 1930 and taught there until 1965. From 1928 to 1937 he also taught at the Portuguese Military Academy and between 1933 and 1934 was visiting professor at Imperial College, London. He was the director of the Geophysical Institute Infante $D$. Luis in Lisbon from 1937 to 1964 . In 1943 he was charged with the reorganisation of the National Meterological Service, which he directed until 1965. He was an Under Secretary of State for Education from 1944 to 1946.

\section{J. Chamberlain}

John Chamberlain died on October 11, 1974. He was 37.

He took his doctorate from Imperial College, London in 1962 and was appointed that year to the National Physical Laboratory. There, for the rest of his career, he worked on submillimetre wave Fourier Transform spectrometry and refractometry. He made important theoretical and practical contributions to precise measurements and was an authority on the high frequency dielectric properties of materials, including solids, liquids, gases and plasmas.

\section{Announcements}

\section{Appointments}

Bernard Isaacs has been appointed to the Hayward Chair of Geriatric Medicine at the University of Birmingham.

H. A. Lee has been appointed to the chair of metabolic medicine at the University of Southampton.

George Edward Mawer has been appointed to the chair of clinical pharmacology at the University of Manchester.

I. C. Whitfield has been appointed to the personal chair of neurocommunications at the University of Birmingham.

\section{Awards}

Julian G. Edwards has been awarded the 1974 Achievement Award of The Worshipful Company of Scientific Instrument Makers for his development of a Pulsed Energy Laser Monitor.

Maurice Ewing has becn awarded posthumously the Penrose Medal of The Geological Society of America.
Alfred Edward Ringwood has been awarded the Arthur L. Day Medal of The Geological Society of America.

The Chemical Society is offering an additional award in 1974 which has been sponsored by the British Oxygen Company Limited. The award will be made to the author of the best original paper or papers issued in the past five years (since January 1, 1970) covering the chemistry and/or usage of oxygen. This award is available to men and women of British Nationality, including Commonwealth Citizens or those normally domiciled in the British Isles, and is not limited to Fellows of the Chemical Society.

Nominations and/or applications should be sent to Dr John F. Gibson, The Chemical Society, Burlington House, London W1V OBN not later than January 31, 1975 and the relevant paper(s) must accompany any such nomination/application.

\section{Miscellaneous}

The Hollandsche Maatschappij der Wetenschappen (Dutch Society of Sciences) has the intention of publishing the correspondence of Professor H. A. Lorentz (1853-1928), who was Secretary to the Society during the last eight years of his life.

The editing committee would therefore greatly appreciate receiving any information from persons and institutions having in their possession or under their custody letters written by Professor Lorentz, and to receive copies of these letters with the permission for their publication.

Please address all correspondence to: Hollandsche Maatschappij der Wetenschappen (Lorentz Committee), Spaarne 17, Haarlem, The Netherlands.

\section{International meeting}

January 8, Chemical Properties of Drugs, London (Dr R. A. Webster, Department of Pharmacology, University College, London WC1).

\section{Reports and publications}

\section{Great Britain}

Government and the Quality of Life. By Robert Cooke. Pp. 16. (London: Conservative Publications Centre, 32 Smith Square, SW1, 1974.) [189 Information Engineering and Society. By F. J. M. Laver. (The Ninth Maurice Lubbock Memorial Lecture, 1st March, 1974.) Pp. 18. (London: Oxford University Press, 1974.) 30p net. [199 Builetin of the British Museum (Natural History). Entomology. Supplement No. 22: A Revision of the Old World Genus Zamarada (Lepidoptera: Geometridae). By D. S. Fletcher. Pp. $498+123$ plates.
(London: British Museum (Natural History), 1974.) (London: British Museum (Natural History), 1974.)
[209

Advice to Lecturers: An Anthology Taken from the Writings of Michael Faraday and Lawrence Bragg. Edited with an introduction by Sir George Porter, F. R.S., and James Friday. Pp. 18 + 4 plates. (London: Mansell Information/Publishing, Ltd,, 1974. Published for The Royal Institution.) 85p; $\$ 1.98$. 1110 Practical Implications of a Non-Profit Economy. (Proceedings of a Symposium co-sponsored by The Sunday Times and The Science Policy Foundation on 26th June, 1974, at the Royal Festival Hall, London. Edited by Maurice Goldsmith. Pp. 59. (London: Science Policy Foundation, Ltd., 1974.) $£ 1.50$. 110
Bulletin of the British Museum (Natural History). Bulletin of the British Museum (Natural History). Mineralogy. Vol, 2, No. 8: The Naturally Occurring Chromates of Lead. By S. A. Williams. Pp. 377-319. 1.95. Zoology. Vol. 27, No. 4: A Review of Scotoecus Thomas, 1910, (Chiroptera: Vespertilionidae). By J. E. (Natural History), 1974.) 